\title{
Effect of Time of Sugarcane Harvest on Sucrose Content and Sugar Yield ${ }^{1}$
}

\author{
S. Alers-Alers and M. A. Lugo-López²
}

\begin{abstract}
Twelve field experiments with six sugarcane varieties were planted in randomized block designs at four locations (three experiments in each area). One at each location was planted in January; the second in March; and the third in May. Results were pooled and analyses of variance performed, irrespective of location, for sucrose content, and cane and sugar yield per acre of the plant crop, the ratoon crop, and the combined plant crop-ratoon crop. These analyses indicated that for harvesting at 12 months, cane harvested in mid-March was higher in sucrose content and yielded more cane and sugar than that harvested in mid-January or mid-May.
\end{abstract}

\section{INTRODUCTION}

Sugarcane sucrose content has declined in Puerto Rico throughout the past two decades from $11.04 \%$ in 1956 to $8.5 \%$ in $1974-75$. The lowest value, $6.7 \%$, was registered in 1972 . Since the annual production of sugarcane is roughly about 3.5 million tons, this downward trend in sucrose causes a considerable loss of income.

It is very important to maintain or increase sucrose yield, because of its effect on the sugarcane industry and on the economy of the Island. During the past decade Puerto Rico has not been able to meet its sugar quota.

Management studies with new sugarcane varieties of outstanding performance can help to maintain or improve sugar yield per acre. This work was undertaken to solve part of this problem by studying the various harvesting schedules for different varieties to improve yields and profits per acre.

Some outstanding sugarcane varieties have been recently tested in different ecological regions of Puerto Rico. Maturity studies underway may lead to better methods of timing harvest of specific varieties. Research $(1,3,4,6)$ indicates that the influence of age and time of the year the cane is harvested must both be evaluated. Maturity studies (5) have been conducted in a limited way with PR 980, a late-maturing variety yielding high tonnage, but low sucrose content. These studies indicate that when this variety is harvested at age 13 months or more, independently of the month of harvest, very good sugar yields per acre are obtained. Management studies $(2,3)$ have been conducted with varieties PR 980, PR 1059, PR 1013, PR 1016, PR 1028, PR 1048, PR 975, H $32-$

1 Manuseript submitted to Editorial Board January 26, 1976.

${ }^{2}$ Associate Agronomist, and Professor and Soil Scientist, respectively, Agricultural Experiment Station, University of Puerto Rico, Río Piedras, P.R. 
8560, B 4362, and B 37-172. The results indicate that PR 1059 has the potential to produce a high sucrose content throughout the whole harvesting period, but that it is an early or intermediate maturing variety. PR 1016 and PR 1028 perform better as early varieties.

This paper reports on the effect of time of harvest of 12-month old cane on tonnage, sucrose content, and sugar yields. It includes six varieties harvested at three different times of the year at four locations.

\section{MATERIALS AND METHODS}

Twelve field experiments were conducted in four different ecological areas throughout the Island, three in each area, planted bimonthly from January to May. The plantings were at Isabela, Lajas, Ponce, and Yabucoa.

TABLE 1.-Mean sucrose, cane, and sugar yields of six sugarcane varieties at various times of harvest, plant cane

\begin{tabular}{|c|c|c|c|c|c|c|}
\hline $\begin{array}{c}\text { Time of } \\
\text { harvesting }\end{array}$ & PR 1016 & PR 1028 & PR 980 & PR 1048 & PR 1059 & B-37-172 \\
\hline \multicolumn{7}{|c|}{ Sucrose, \% } \\
\hline January & $12.39 \mathrm{a}^{1}$ & $11.98 \mathrm{a}$ & $11.05 \mathrm{a}$ & $11.67 \mathrm{a}$ & $13.18 \mathrm{a}$ & $11.37 \mathrm{a}$ \\
\hline March & $13.20 \mathrm{a}$ & $12.41 \mathrm{a}$ & $12.30 \mathrm{~b}$ & $12.56 \mathrm{a}$ & $14.32 \mathrm{~b}$ & $12.79 \mathrm{~b}$ \\
\hline May & $12.82 \mathrm{a}$ & $12.25 \mathrm{a}$ & $11.91 \mathrm{ab}$ & $12.52 \mathrm{a}$ & $13.18 \mathrm{a}$ & $11.87 \mathrm{a}$ \\
\hline \multicolumn{7}{|c|}{ Cane, tons/acre } \\
\hline January & $46.18 \mathrm{a}$ & $48.20 \mathrm{a}$ & $57.81 \mathrm{a}$ & $49.25 \mathrm{a}$ & $43.37 \mathrm{a}$ & $49.12 \mathrm{a}$ \\
\hline March & $54.43 \mathrm{a}$ & $54.87 \mathrm{a}$ & 59.87 a & $53.93 \mathrm{a}$ & $46.00 \mathrm{a}$ & $53.37 \mathrm{a}$ \\
\hline May & $52.06 \mathrm{a}$ & $48.93 \mathrm{a}$ & 56.93 a & $51.56 \mathrm{a}$ & $47.93 \mathrm{a}$ & $54.31 \mathrm{a}$ \\
\hline \multicolumn{7}{|c|}{ Sugar, tonslacre } \\
\hline January & $5.78 \mathrm{a}$ & $5.85 \mathrm{a}$ & $6.45 \mathrm{a}$ & $5.81 \mathrm{a}$ & $5.8 \bar{a}$ & $5.63 \mathrm{a}$ \\
\hline March & $7.22 \mathrm{a}$ & $6.88 \mathrm{a}$ & $7.34 \mathrm{a}$ & $6.77 \mathrm{a}$ & $6.68 \mathrm{a}$ & $6.85 \mathrm{a}$ \\
\hline May & $6.69 \mathrm{a}$ & $6.07 \mathrm{a}$ & $6.77 \mathrm{a}$ & $6.41 \mathrm{a}$ & $6.36 \mathrm{a}$ & $6.44 \mathrm{a}$ \\
\hline
\end{tabular}

${ }^{1}$ Differences between means without letters in common are significant $(\mathrm{P}<0.05)$.

The soil at the experimental site at the Isabela Substation in northwestern Puerto Rico is Coto, a Tropeptic Haplortox, clayey, kaolinitic, isohyperthermic. That at the Lajas Substation in southwestern Puerto Rico is Fraternidad, one of the Udic Chromusterts, very fine, montmorillonitic, isohyperthermic. At Ponce, on the southern coast, the soil is Cintrona, a Typic Calciaquolls, fine, mixed, isohyperthermic. At Yabucoa, in eastern Puerto Rico, the soil is Talante, an Aeric Tropic Fluvaquents, coarse-loamy over sandy, mixed, acid, isohyperthermic.

All experiments followed randomized block design with six varieties and six replications. Plots were 24 by $20 \mathrm{ft}(7.32 \times 6.09 \mathrm{~m})$. Varieties included in each experiment were: PR 1016, PR 1028, PR 980, PR 1048, PR 1059, and B 37-172. They were planted at each site in January, March, and May for each corresponding experiment. Rows $4 \mathrm{ft}$ apart were planted with 3 -eye seed-pieces at the rate of 12,000/acre. Fertilizer (15-5-10) was used as follows: at Isabela, $700 \mathrm{lb} / a c r e$, at Lajas, $700 \mathrm{lb} /$ 
acre, $400 \mathrm{lb}$ at planting and $300 \mathrm{lb} 3$ months later. At Ponce, $200 \mathrm{lb}$ urea/ acre at planting time and $500 \mathrm{lb}$ of 15-5-10/acre 2 months later; and at Yabucoa, $800 \mathrm{lb}$ 15-5-10/acre, $400 \mathrm{lb}$ at time of planting and $400 \mathrm{lb} 3$ months later. The same blanket application of fertilizer was used for the ratoon crops in all experiments. Cultivation and crop management practices followed the pattern used by commercial growers in each corresponding area.

Cane was harvested at 12 months for both the plant cane and the ratoon crops. At harvest time, 15-cane samples from each plot were taken to determine sucrose content. Total cane from each entire plot was weighed to determine cane yield. From sucrose-content and cane ton-

TABLE 2.-Mean sucrose, cane, and sugar yields of six sugarcane varieties at various times of harvest, ratoon crop

\begin{tabular}{|c|c|c|c|c|c|c|}
\hline $\begin{array}{c}\text { Time of } \\
\text { harvesting }\end{array}$ & PR 1016 & PR 1028 & PR 980 & PR 1048 & PR 1059 & B- $-37-172$ \\
\hline \multicolumn{7}{|c|}{ Sucrose, \% } \\
\hline January & $11.02 \mathrm{a}^{1}$ & $11.24 \mathrm{a}$ & $10.30 \mathrm{a}$ & $10.61 \mathrm{a}$ & $11.38 \mathrm{a}$ & $10.20 \mathrm{a}$ \\
\hline March & $12.07 \mathrm{a}$ & $12.15 \mathrm{a}$ & $11.15 \mathrm{a}$ & $11.74 \mathrm{a}$ & $12.81 \mathrm{a}$ & $12.09 \mathrm{~b}$ \\
\hline May & $12.02 \mathrm{a}$ & $11.55 \mathrm{a}$ & $11.23 \mathrm{a}$ & $11.89 \mathrm{a}$ & $12.78 \mathrm{a}$ & $11.69 \mathrm{ab}$ \\
\hline \multicolumn{7}{|c|}{ Cane, tons/acre } \\
\hline January & $50.37 \mathrm{a}$ & $45.93 \mathrm{a}$ & $64.18 \mathrm{a}$ & $51.50 \mathrm{a}$ & $41.93 \mathrm{a}$ & $41.00 \mathrm{a}$ \\
\hline March & $54.75 \mathrm{a}$ & $50.37 \mathrm{a}$ & $64.06 \mathrm{a}$ & $58.43 \mathrm{a}$ & $41.25 \mathrm{a}$ & $51.00 \mathrm{a}$ \\
\hline May & $48.81 \mathrm{a}$ & $43.75 \mathrm{a}$ & $58.87 \mathrm{a}$ & 50.18 a & $37.25 \mathrm{a}$ & $45.00 \mathrm{a}$ \\
\hline \multicolumn{7}{|c|}{ Sugar, tons/acre } \\
\hline January & $5.29 \mathrm{a}$ & $5.22 \mathrm{a}$ & $6.50 \mathrm{a}$ & $5.83 \mathrm{a}$ & $4.86 \mathrm{a}$ & $4.19 \mathrm{a}$ \\
\hline March & $6.45 \mathrm{~b}$ & $6.13 \mathrm{a}$ & $7.06 \mathrm{a}$ & $6.80 \mathrm{a}$ & $5.34 \mathrm{a}$ & $6.13 \mathrm{a}$ \\
\hline May & $5.85 \mathrm{ab}$ & $4.86 \mathrm{a}$ & $6.62 \mathrm{a}$ & $5.74 \mathrm{a}$ & $4.76 \mathrm{a}$ & $5.12 \mathrm{a}$ \\
\hline
\end{tabular}

${ }^{1}$ Differences between means without letters in common are significant $(\mathrm{P}<0.05)$.

nage, sugar yields per acre were calculated. Combined yields for a plant crop and a ratoon were also calculated. Results were combined and analyses of variance performed irrespective of location.

\section{RESULTS AND DISCUSSION}

Table 1 shows no significant differences between means of any of the yield components for the plant cane of varieties PR 1016, PR 1028, and PR 1048. Neither were there differences between mean cane and sugar per acre yields for PR 980. However, when varieties PR 1059 and B 37172 were harvested in March, their sucrose contents were significantly higher than those of the same varieties when harvested in January and May. In PR 980, sucrose content from the March harvest was significantly higher than that of January.

For the ratoon crop (table 2), there were no differences in yield whether varieties PR 1028, PR 980, PR 1048, and PR 1059 were harvested in January, March, or May. A higher sugar yield was obtained 
for variety PR 1016 when harvested in March than when harvested in January. B 37-172 had higher mean sucrose yields when harvested in March than in January.

Table 3 presents the combined yields for each variety. Differences were observed only in sucrose contents of varieties PR 980, PR 1048, PR 1059, and B 37-172. Mean sucrose percentages of PR 980 and PR 1059 for the March harvest were significantly higher than for January, though

TABLE 3.-Combined mean sucrose, cane, and sugar yields of six sugarcane varieties at various times of harvest, plant crop and ratoon crop

\begin{tabular}{|c|c|c|c|c|c|c|}
\hline $\begin{array}{l}\text { Time of } \\
\text { harvesting }\end{array}$ & PR 1016 & PR 1028 & PR 980 & PR 1048 & PR 1059 & B-37-172 \\
\hline \multicolumn{7}{|c|}{ Sucrose, \% } \\
\hline January & $11.70 \mathrm{a}^{1}$ & $11.60 \mathrm{a}$ & $10.67 \mathrm{a}$ & $11.13 \mathrm{a}$ & $12.24 \mathrm{a}$ & $10.78 \mathrm{a}$ \\
\hline March & $12.63 \mathrm{a}$ & $12.27 \mathrm{a}$ & $11.72 \mathrm{~b}$ & $12.15 \mathrm{~b}$ & $13.57 \mathrm{~b}$ & $12.44 \mathrm{~b}$ \\
\hline May & $12.41 \mathrm{a}$ & $11.89 \mathrm{a}$ & $11.56 \mathrm{ab}$ & $12.20 \mathrm{~b}$ & $12.98 \mathrm{ab}$ & $11.78 \mathrm{~b}$ \\
\hline \multicolumn{7}{|c|}{ Cane, tons/acre } \\
\hline January & $48.27 \mathrm{a}$ & $46.88 \mathrm{a}$ & $60.69 \mathrm{a}$ & $50.37 \mathrm{a}$ & $42.56 \mathrm{a}$ & $45.05 \mathrm{a}$ \\
\hline March & $54.59 \mathrm{a}$ & $52.62 \mathrm{a}$ & $61.96 \mathrm{a}$ & $56.18 \mathrm{a}$ & $43.62 \mathrm{a}$ & $52.18 \mathrm{a}$ \\
\hline May & $51.09 \mathrm{a}$ & $47.34 \mathrm{a}$ & 58.47 a & $51.81 \mathrm{a}$ & $42.58 \mathrm{a}$ & $50.68 \mathrm{a}$ \\
\hline \multicolumn{7}{|c|}{ Sugar, tons/acre } \\
\hline January & $5.66 \mathrm{a}$ & $5.51 \mathrm{a}$ & $6.47 \mathrm{a}$ & $5.60 \mathrm{a}$ & $5.31 \mathrm{a}$ & $4.91 \mathrm{a}$ \\
\hline March & $6.83 \mathrm{a}$ & $6.50 \mathrm{a}$ & $7.20 \mathrm{a}$ & $6.78 \mathrm{a}$ & $6.01 \mathrm{a}$ & $6.48 \mathrm{a}$ \\
\hline May & $6.40 \mathrm{a}$ & $5.65 \mathrm{a}$ & $6.75 \mathrm{a}$ & $6.23 \mathrm{a}$ & $5.55 \mathrm{a}$ & $5.92 \mathrm{a}$ \\
\hline
\end{tabular}

${ }^{1}$ Differences between means without letters in common are significant $(\mathrm{P}<0.05)$.

not significantly different from the May harvest. The sucrose contents of PR 1048 and B 37-172 for March and May harvests were not significantly different, but both outyielded significantly the corresponding sucrose contents of the January harvest.

These results indicate that when sugarcane is to be harvested at the age of 12 months, the varieties used herein should be planted during March, at least in the areas where these experiments were conducted, in order to obtain maximum sucrose content and sugar yields.

\section{RESUMEN}

Se realizaron 12 experimentos de campo en cuatro localidades (tres en cada sitio) con las variedades de caña de azúcar PR 980, PR 1059, PR 1016, PR 1028, PR 1048 y B 37-172. En cada localidad se sembró un experimento siguiendo un diseño de bloques al azar, en enero, otro en marzo y otro en mayo. En cada experimento, la caña se cosechó a los 12 meses de edad. Los datos de plantilla y retoño de cada experimento se analizaron conjuntamente, sin considerar las variaciones atribuidas a la localidad. La cosecha de marzo produjo los rendimientos máximos de sacarosa para la plantilla de PR 980, PR 1059 y B 37-117. El retoño de PR 1016 cosechado en marzo, produjo más azúcar que cuando se cosechó en enero. También se obtuvieron valores más altos para sacarosa en marzo que en enero para la variedad B 37-172. El análisis estadístico combinado para la plantilla y el retoño demuestra que a los 12 meses de edad las variedades PR 980, PR 1059, PR 1048 y B 37-172 producen más sacarosa si se cosechan en marzo que si se cosechan en enero. 


\section{LITERATURE CITED}

1. Alers-Alers, S., A study on growth rate and sucrose content of three sugarcane varieties as indices of their maturity. A thesis submitted in partial fulfillment of the requirements for the degree of Master of Science, Univ. P.R., Mayagüez Campus, May, 1968.

2. — Juliá, F., and Lugo-López, M. A., Effect of harvesting sugarcane at 12, 14 and 16 months of age upon yields at Isabela, P.R., J. Agr. Univ. P.R. 57(1): 1-8, 1973.

3. —, Lugo-López, V. A., and Gandía-Caro, R., Production for 12-18- and 24-month cycles under conditions in Puerto Rico, J. Agr. Univ. P.R. 56(1): 110-27, 1960

4. __ Samuels, G., and Landrau, Jr. P., Influence of time of planting on the growth of sugarcane variety PR. 980 at Rio Piedras, P.R., J. Agr. Univ. P.R. 44(2): 45-52, 1960

5. Capó, B. G., La influencia de la edad y la épuca de la cosecha sobre el contenido de azúciar y la producción de caña y azúcar, Agr. Exp. Sta., Univ. P.R. Bol. 227, 1970.

6. Simuels, G., Alers-Alers, S., and Landrau, Jr. P., The influence of time of harvest and age of 16 sugarcane varieties on their sucrose content, J. Agr. Univ. P.R. $44(1): 1-10,1960$. 